\title{
The Contributions of Selected Diseases to Disparities in Death Rates and Years of Life Lost for Racial/Ethnic Minorities in the United States, 1999-2010
}

George Howard, DrPH; Frederick Peace, MS; Virginia J. Howard, PhD

Suggested citation for this article: Howard G, Peace F, Howard VJ. The Contributions of Selected Diseases to Disparities in Death Rates and Years of Life Lost for Racial/Ethnic Minorities in the United States, 1999-2010. Prev Chronic Dis 2014;11:140138. DOI: http://dx.doi.org/10.5888/pcd11.140138

PEER REVIEWED

\section{Abstract}

\section{Introduction}

Differences in risk for death from diseases and other causes among racial/ethnic groups likely contributed to the limited improvement in the state of health in the United States in the last few decades. The objective of this study was to identify causes of death that are the largest contributors to health disparities among racial/ethnic groups.

\section{Methods}

Using data from WONDER system, we measured the relative (age-adjusted mortality ratio [AAMR]) and absolute (difference in years of life lost [dYLL]) differences in mortality risk between the non-Hispanic white population and the black, Hispanic, American Indian/Alaska Native, and Asian/Pacific Islander populations for the 25 leading causes of death.

\section{Results}

Many causes contributed to disparities between non-Hispanic whites and blacks, led by assault (AAMR, 7.56; dYLL, 4.5 million). Malignant neoplasms were the second largest absolute contributor (dYLL, 3.8 million) to black-white disparities; we also found substantial relative and absolute differences for several cardiovascular diseases. Only assault, diabetes, and diseases of the liver contributed substantially to disparities between non-Hispanic whites and Hispanics (AAMR $\geq 1.65$; dYLL $\geq 325$, Ooo). Many causes of death, led by assault (AAMR, 3.25; dYLL, 98,00o), contributed to disparities between non-Hispanic whites and American Indians/Alaska Natives; Asian/Pacific Islanders did not have a higher risk than non-Hispanic whites for death from any disease.

\section{Conclusion}

Assault was a substantial contributor to disparities in mortality among non-Asian racial/ethnic minority populations. Research and intervention resources need to target diseases (such as diabetes and diseases of the liver) that affect certain racial/ethnic populations.

\section{Introduction}

A recent report underscored dramatic improvements in the state of health in the United States but also noted that improvements have not been as rapid as they have been in other wealthy nations (1). Differential risk in subpopulations (health disparities) is a likely contributor to this shortfall. Life expectancy differs among racial/ethnic groups; in 2006, life expectancy for whites was 78.5 years, lower than the life expectancy for Asians (86.6 y) or Hispanics (82.8 y) but higher than the life expectancy for blacks (73.4 y) or American Indians or Alaska Natives (74.2 y) (2). However, differences in life expectancy do not account for racial/ethnic differences in causes of death.

The Minority Health and Health Disparities Research and Education Act of 2000 requires the National Institutes of Health to study health disparities among racial/ethnic groups. However, the law does not provide guidance for allocating resources for research on specific diseases or racial/ethnic groups. One study noted a confounding of race and region, with different life expectancies for whites in Appalachia and whites in the Mississippi Valley, low-income rural whites in the northern plains and the Dakotas, and whites from other regions; and different life expectancies for southern low-income rural blacks, high-risk urban blacks, and other blacks (3).

Because of limited funding to investigate disparities, resources should be allocated according to the impact of the disparity. Should this allocation be driven by data on relative differences or data on absolute differences? Suppose 2 diseases are competing for resources. The first disease demonstrates a large relative difference in mortality risk among racial/ethnic groups; however, the disease is rare, or the racial/ethnic group affected is small. The second disease demonstrates a small relative difference in mortality risk among racial/ethnic groups, but the disease is common, and the racial/ethnic group affected is large, so the disease and the disparity affect many people. There is value in addressing both large relative and large absolute differences in mortality risk. The objective of this study was to provide measures of relative and absolute differences in mortality risk for the 25 leading causes of death 
in 5 racial/ethnic groups: American Indians and Alaska Natives (AIAN), Asians and Pacific Islanders (API), blacks, Hispanics, and non-Hispanic whites.

\section{Methods}

Data were retrieved from the Wide-Ranging Online Data for Epidemiologic Research (WONDER) system supported by the Centers for Disease Control and Prevention (4). In 1999, the WONDER system converted codes for cause of death to International Classification of Diseases, 10th Revision (ICD-10) codes; data are available for a 12-year period through 2010. For each ICD-10 subchapter, we first retrieved data on the number of deaths and calculated the total number of person-years at risk by summing the population in each of the 12 study years. We then tabulated age-adjusted (to the 2000 US population) mortality rates for each racial/ethnic group (non-Hispanic white, black, Hispanic, American Indian/Alaska Native [AIAN], Asian/Pacific Islander [API]). Because the number of deaths was too small to provide stable estimates, our racial/ethnic classification excluded a small number of Hispanic AIAN, Hispanic API, and Hispanic blacks from the analyses (collectively 4,072,827 of 3,530,708,204 [0.1\%] of the total person-years at risk).

The relative measure of disparity was the age-adjusted mortality ratio (AAMR), calculated as the age-adjusted mortality rate for the racial/ethnic minority group of interest divided by the age-adjusted mortality rate for non-Hispanic whites. The absolute measure of disparity was difference in years of life lost (dYLL), derived by first calculating the "excess" (or "deficit") number of deaths in each age

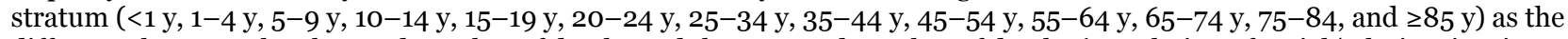
difference between the observed number of deaths and the expected number of deaths (population of racial/ethnic minority group $\times$ age stratum death rate for non-Hispanic whites) for the stratum. For each age stratum, the sum of the expected years of life was calculated from the non-Hispanic white life table (5), and the dYLL calculated as the sum of the years of life lost across the age strata.

In our initial analysis, the top 25 causes of death included only $86 \%$ of the deaths for the black and Hispanic populations and $87 \%$ for the AIAN population; this raised the possibility that other diseases could be important in these populations. A post hoc analysis examined the next 25 leading causes of death.

\section{Results}

Overall, the 25 leading causes of death caused $90 \%$ of all deaths (Table 1). Malignant neoplasms ranked first as cause of death among all racial/ethnic groups, according to age-adjusted mortality rates (Table 2).

For the black population, the largest AAMR (7.56) and largest dYLL (4.5 million) was for assault (Figure, Panel A, and Supplemental Table 1 in the Appendix). Because malignant neoplasm was a common cause of death, it contributed to the second largest dYLL (nearly 3.8 million) despite a small AAMR (1.22). Similarly, ischemic heart disease (AAMR, 1.19; dYLL, 2.7 million), other forms of heart disease (AAMR, 1.27; dYLL, 2.0 million), and cerebrovascular disease (AAMR, 1.44; dYLL, 2.0 million) had modest AAMRs but contributed to large dYLLs. In contrast, hypertensive diseases (AAMR, 2.99; dYLL, 2.3 million), diabetes (AAMR, 2.23; dYLL, 1.8 million), renal failure (AAMR, 2.35; dYLL, 1.2 million), and other bacterial diseases (AAMR, 2.20; dYLL, 980,000) were less common causes of death, but their higher relative risk contributed to large dYLLs. 
Preventing Chronic Disease $\mid$ The Contributions of Selected Diseases to Disparities in De... Page 3 of 18

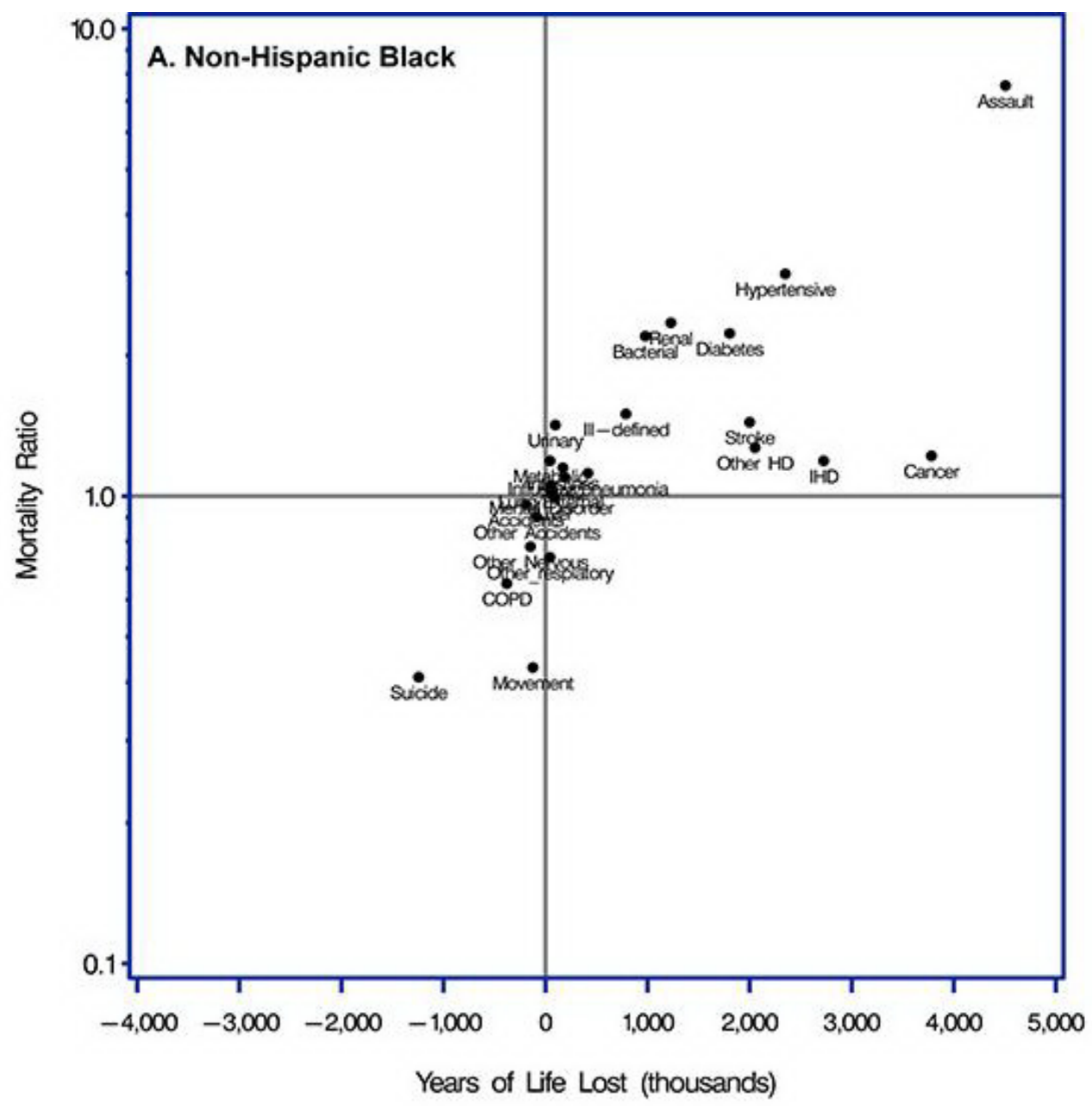


Preventing Chronic Disease $\mid$ The Contributions of Selected Diseases to Disparities in De... Page 4 of 18

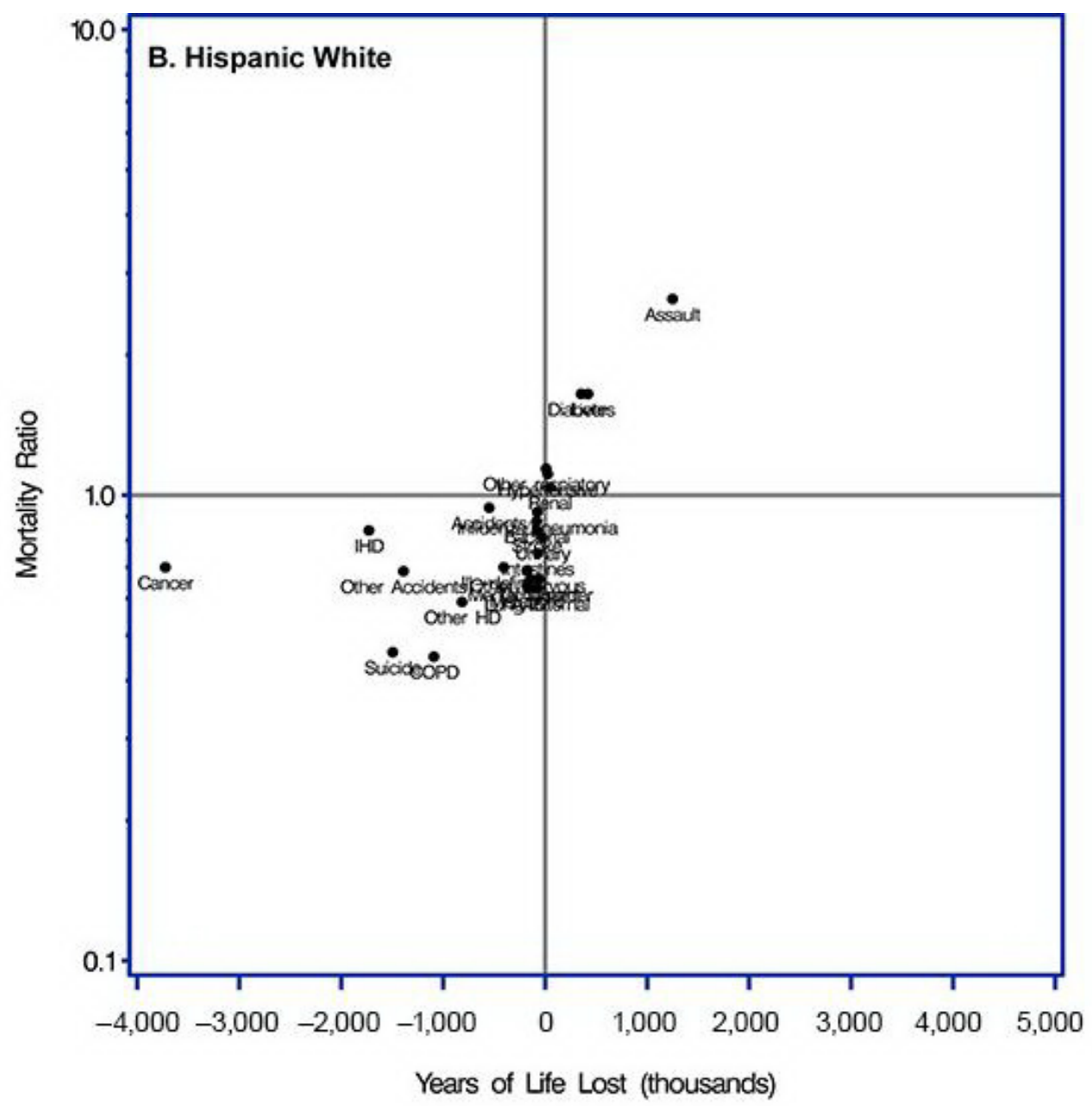


Preventing Chronic Disease $\mid$ The Contributions of Selected Diseases to Disparities in De... Page 5 of 18

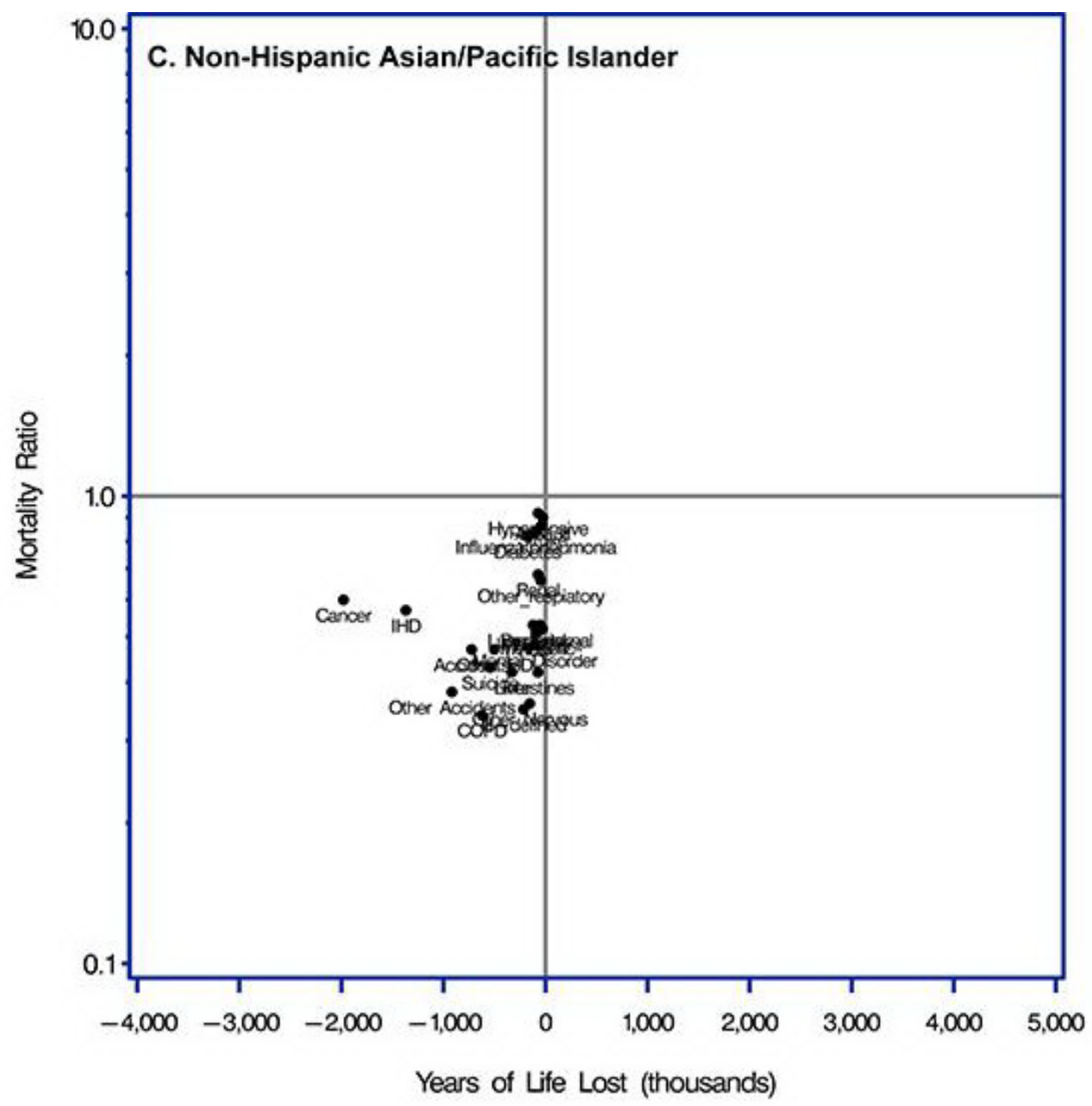




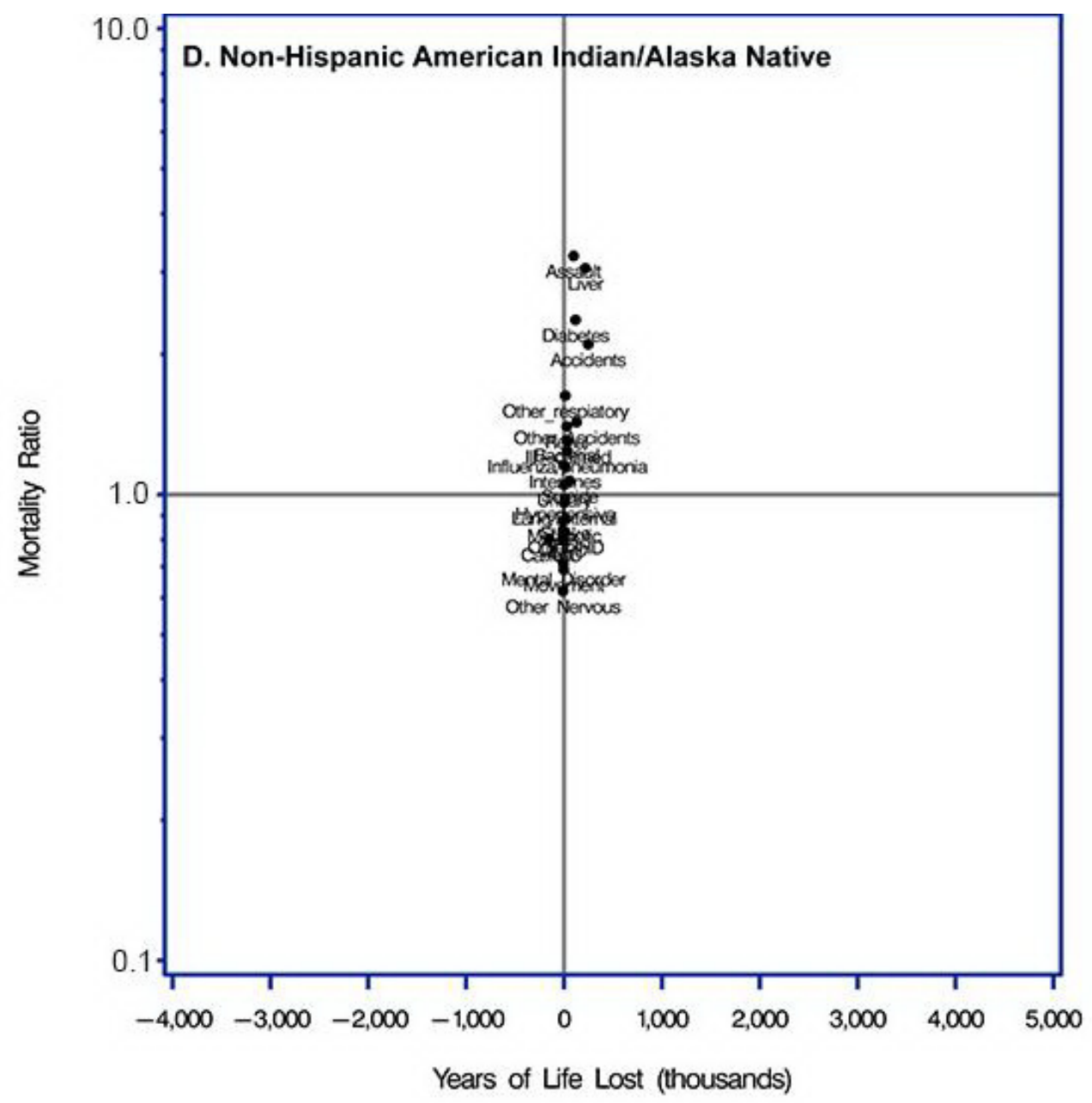

Figure. Scatterplots of relative measure of disparities (age-adjusted mortality ratio [AAMR]) and absolute measures of disparities (difference in years of life lost [dYLL]) for each of 4 racial/ethnic minority groups compared with the non-Hispanic white population for the 25 leading causes of death in the United States, 1999-2010. Causes of death were categorized according to the International Classification of Diseases, $10^{\text {th }}$ Revision. Scatterplot A is for non-Hispanic blacks; B for Hispanic whites; C for non-Hispanic Asians/Pacific Islanders; and D for non-Hispanic American Indians/Alaska Natives. Abbreviations for categories of causes of death were used to provide clearer plots. Abbreviations: Cancer, malignant neoplasms; IHD, ischemic heart disease; Other HD, other forms of heart disease; Stroke, cerebrovascular disorders; COPD, chronic lower respiratory diseases; Diabetes, diabetes mellitus; Other Nervous, other degenerative diseases of the nervous system; Other Accidents, other external causes of accidental injury; Mental Disorder, organic, including symptomatic, mental disorders; Influenza/Pneumonia, influenza or pneumonia; Hypertensive, hypertensive diseases; Transport, transport accidents; Renal, renal failure; Liver, diseases of the liver; Bacterial, other bacterial diseases; AAC, diseases of the arteries, arterioles or capillaries; Suicide, intentional self-harm; Intestines, other diseases of the intestines; Movement, extrapyramidal or movement disorders; Lung/External, lung diseases due to external agents; Assault, assault; III-Defined, ill-defined or unknown causes of mortality; Other Respiratory, other respiratory diseases principally affecting the interstitium; Metabolic, metabolic disorders; Urinary, other diseases of the urinary systems.

Blacks had a lower risk for death from several causes than did whites. Among those causes, the largest dYLL between blacks and whites was for intentional self-harm (AAMR, 0.41 ; dYLL $=-1.2$ million). Blacks had a lower relative risk for death from extrapyramidal or movement disorders (AAMR, 0.43; dYLL = -123,000), chronic lower respiratory diseases (AAMR, o.65; dYLL, -379,000), other respiratory diseases principally affecting the interstitium (AAMR, 0.74; dYLL, -44,0oo), and other degenerative diseases of the nervous system (AAMR, 0.78; dYLL, -147,000), but these diseases generally contributed to small dYLLs.

Assault was the largest relative and absolute contributor to disparities between whites and Hispanics (AAMR, 2.64; dYLL, 1.2 million) (Figure, Panel B, and Supplemental Table 1). However, the Hispanic population had a substantially higher risk for death from only 2 other causes: diseases of the liver (AAMR, 1.65; dYLL, 421,000) and diabetes (AAMR, 1.65; dYLL, 353,00o). The Hispanic population had a lower risk than whites for death from malignant neoplasms (AAMR, 0.70; dYLL, -3.7 million) and ischemic heart disease (AAMR, 0.84; dYLL, -1.7 million), and both common diseases contributed to large dYLLs. Hispanics had substantially lower risk for death from intentional self-harm (AAMR, 0.47; dYLL, -1.5 million), chronic lower respiratory diseases (AAMR = 0.45; dYLL, -1.1 million), other external causes of accidental injury (AAMR, 0.69; dYLL, -1.4 million), and other forms of heart diseases (AAMR, 0.59; dYLL, $-814,000$ ), and these substantially lower relative risks contributed to large dYLLs.

The AIAN population had a higher risk than the white population for death from several causes (Figure, Panel C, and Supplemental Table 1); however, the smaller size of the AIAN population contributed to modest dYLLs. Higher relative risks for death from assault 
(AAMR, 3.25; dYLL, 98,000) and diseases of the liver (AAMR, 3.06; dYLL, 218,00o) were striking, but they contributed to small dYLLs; differences in risk for death from diabetes (AAMR, 2.37; dYLL, 118,0oo) and transportation accidents (AAMR, 2.10; dYLL, 248,000) also contributed to small dYLLs. Many other diseases posed a higher risk for the AIAN population than for whites, including other respiratory diseases principally affecting the interstitium (AAMR,1.64; dYLL, 14,000), renal failure (AAMR, 1.40; dYLL, 28,000), other bacterial diseases (AAMR, 1.31; dYLL, 28,00o), influenza and pneumonia (AAMR, 1.24; dYLL, 34,000), illdefined or unknown causes of mortality (AAMR, 1.30; dYLL, 40,000), and other diseases of the intestine (AAMR, 1.15; dYLL, 8,0oo).

The AIAN population had a lower risk for death than the white population from several diseases, including other degenerative diseases of the nervous system (AAMR, 0.62; dYLL, -11,000), extrapyramidal and movement disorders (AAMR, 0.69; dYLL, $-3,000$ ), and organic mental disorders (AAMR, 0.71, dYLL, -7,000). In addition, the AIAN population had a lower relative risk for all 5 leading causes of death: malignant neoplasms (AAMR, o.80; dYLL, -158), ischemic heart diseases (AAMR = 0.84; dYLL, -12,00o), other forms of heart disease (AAMR, 0.83; dYLL, 14,000), cerebrovascular disease (AAMR, 0.89; dYLL, 13K), and chronic lower respiratory diseases (AAMR, 0.82; dYLL, -14,000).

Finally, the API population had neither a higher relative risk nor a higher absolute risk than the white population for any cause of death, but it did have substantially fewer years of life lost and a lower risk for death from malignant neoplasms (AAMR, o.60; dYLL, -2.0 million) and ischemic heart disease (AAMR, 0.57; dYLL, -1.4 million) (Figure, Panel D, and Supplemental Table 1).

The post hoc analysis of the 26th- to 5oth-ranked causes of death (Supplemental scatterplots in Appendix and Supplemental Table 2) showed a pattern similar to that for the leading 25 causes of death. Numerous diseases contributed to disparities between whites and blacks and between whites and the AIAN population, whereas few diseases contributed to disparities between whites and Hispanics and between whites and the API population. Human immunodeficiency virus (HIV) was the 29th leading cause of death overall; for blacks, the AAMR was a remarkable 10.8 (dYLL, 2.9 million), placing HIV among the major contributors to disparities in mortality for blacks. HIV also played a substantial role in disparities for the Hispanic (AAMR, 2.80; dYLL, 449,000) and AIAN (AAMR, 1.60; dYLL, 12,00o) populations. Childhood diseases were particularly noteworthy contributors to disparities between whites and blacks, especially disorders related to the length of gestation and fetal growth (AAMR, 3.79; dYLL, 1.3 million) and respiratory and cardiovascular disorders specific to the perinatal period (AAMR, 2.59; dYLL, 648,00o). For Hispanics, only viral hepatitis (AAMR, 3.65; dYLL, 124,000) was a striking contributor to disparities. For the AIAN population, substantial contributors to disparities were substance abuse (AAMR, 3.27; dYLL, 2,000), viral hepatitis (AAMR, 1.82; dYLL, 63,000) and systemic connective disease disorders (AAMR, 1.62; dYLL, 36,000). The dearth of diseases contributing to disparities between whites and the API population remained in the post hoc analysis.

\section{Discussion}

A few causes of death had a similar effect across racial/ethnic groups, whereas many others had different effects for different races or ethnicities. Assault played a major role in deaths among the black, Hispanic, and AIAN populations. Diabetes and diseases of the liver were the only other substantial contributors to relative or absolute disparities for the Hispanic population and were also the secondand third-largest contributors to disparities for the AIAN population. In contrast, the 4 leading causes of death (malignant neoplasms, ischemic heart disease, other forms of heart disease, and cerebrovascular disorders) placed blacks at higher risk than whites but placed all other racial/ethnic minority groups at lower risk. Hypertensive diseases, renal diseases, and other bacterial diseases increased disparities for the black population only. Hence, broad prevention strategies related to assault, diseases of the liver, and diabetes could reduce disparities in many racial/ethnic groups; our data suggest the need for targeting resources to certain combinations of causes of death that affect certain racial/ethnic populations more than others.

Compared with whites, the black and AIAN populations had a higher risk for death from numerous causes, while the Hispanic population had a higher risk from only 3 causes (assault, diseases of the liver, and diabetes), and the API population did not have a higher risk than whites from any cause. After assault, the largest dYLLs in any racial/ethnic group resulted from 3 diseases in the black population: malignant neoplasms, ischemic heart disease, and other forms of heart disease; each disease contributed to more than 2.0 million dYLLs. However, none of these 3 diseases contributed to disparities in the Hispanic or API population. Importantly, compared with the Hispanic population and the API population, the white population had a higher risk of death from cancer, ischemic heart disease, and other forms of heart disease. Cerebrovascular disease contributed to a substantial dYLL for the black population but had almost no effect on dYLLs for other racial/ethnic groups. These patterns are reflected in patterns of life expectancy (2), with shorter life expectancies for the black and AIAN populations and longer life expectancies for the Hispanic and API populations than for the white population.

Focusing on relative disparities shifts attention to several additional diseases: risk was more than double for the black population than for the white population for hypertensive diseases (AAMR, 2.99), renal failure (AAMR, 2.35) and other bacterial diseases (AAMR, 2.20); no other disease approached a doubling of risk for any racial/ethnic group.

If diseases related to vascular diseases and its risk factors were clustered (ischemic heart disease, other forms of heart disease, cerebrovascular diseases, diabetes, hypertension, and renal disease), they would contribute a remarkable 12.1 million in dYLL and dominate all other contributors to disparities between blacks and whites (and have little impact on other racial/ethnic groups).

With the goal of improving the health of people in all racial/ethnic groups in the United States, one could also attempt to find the largest disparities for whites by combining data for all other racial/ethnic groups. When we used this approach, we found that whites had 3.2 million in dYLL from intentional self-harm, 2.3 million in dYLL from other external causes of accidental injury, 2.1 million in dYLL from chronic lower respiratory diseases, 2.1 million in dYLL from cancers, and 1.2 million in dYLL from transportation accidents. There seems to be a promising opportunity to study these causes of death that lead to lower life expectancy among whites.

The objective of this paper was to identify the causes of death that contribute the most to relative and absolute measures of disparities in mortality among racial/ethnic groups and thereby provide a framework to guide investigators to efficiently investigate the contributors to (or mechanisms for) these disparities. These contributors and mechanisms will likely differ among causes and 
racial/ethnic groups because of the heterogeneous mixture of individual characteristics (socioeconomic, psychosocial, genetic sources, and physiological) and societal exposures (availability of medical resources, neighborhood characteristics, environmental exposures, and others). Consider, for example, disparities in assault and diabetes. It seems likely that disparities in assault would be tightly tied to socioeconomic and psychosocial sources, whereas differences in diabetes would be driven more by physiological or genetic differences. However, by focusing on race-disease combinations that evidence the greatest disparities, further work can increase understanding of the contribution of specific diseases, and interventions can be developed to reduce these disparities. To make this task even more challenging, there are likely dynamic changes in the impact of diseases as contributors to disparities in mortality associated with shifts in deaths from certain diseases (1) and temporal changes in certain diseases that differ between men and women (6) and between regions of the country (7).

This study has several limitations. The estimates from the WONDER system rely on data from death certificates, introducing 2 concerns. The first is misclassification of race/ethnicity: as noted by Arias and colleagues (8), the numerator of the death rate (the number of deaths) is based on the race/ethnicity indicated on the death certificate, information usually collected by physicians or funeral directors who gather the information from personal observation or from next of kin. The denominator of the death rate, the population size, is based on self-reported race/ethnicity from the US Census. That these data come from different sources introduces the possibility of differential reporting by racial/ethnic group and may affect the magnitude of disparity among racial/ethnic groups. Arias and colleagues concluded that this concern is minimal for data on whites and blacks and modest for Hispanic and API populations but may be substantial for AIAN populations. The second concern is the misclassification of cause of death. One study (9) examined data on underlying cause of death obtained from physician-adjudicated medical records (the gold standard) and compared these data with the underlying cause of death indicated on the death certificate. Considering cause of death on a broad basis, the study found that sensitivity ranged from $31 \%$ (death from infection) to $81 \%$ (death from cancer) and that the positive predictive value ranged from $31 \%$ (death from infection) to $50 \%$ (death from cancer); however, these gaps in the ability to identify diseases on death certificates would be smaller if a finer classification of causes of death existed (eg, an exact cause instead of a broad classification, such as cancer) Hence, misclassification could play a potentially different role across diseases.

Racial/ethnic differences in health exist in many domains that do not result in death and are not identified in these analyses. For example, mental health problems and diabetes have a profound impact on disparities in quality of life that are identified by measures such as the disability-adjusted life year (DALY) or quality-adjusted life year (QALY) but not by measures of mortality. However, it could be argued that events tied to death are the most serious and important and perhaps should be a primary guide to understanding disparities. In addition, several causes of death share risk factors and are correlated. A competing-cause analysis would partially address this question but is not feasible because of the number of causes of death that need to be considered.

In conclusion, although we found similarities in the contribution of causes of death to racial/ethnic disparities, we found larger differences. The importance of finding the contributors to disparities is growing, and without targeted studies the magnitude of disparities will move from bad to worse. For example, despite the remarkable and rapid 37\% decline in stroke mortality (from 173.2 per 100,000 in 1999 to 108.6 per 100,000 in 2009), the black-white stroke disparity increased by $25 \%$ (from a mortality ratio of 1.36 in 1999 to 1.45 in 2009 [10]). Not only are there apparent increases in the geographic disparities in life expectancy (7) but disparities associated with socioeconomic status are likely growing; for example, wealthy counties have larger declines in cigarette smoking than poor counties (11). We hope that our data can be used as a road map to guide a call-to-action to aggressively target the contributors to racial/ethnic disparities and lead to interventions that will reduce them.

\section{Acknowledgments}

This work was supported by cooperative agreement no. Uo1 NSo41588 from the National Institute of Neurological Disorders and Stroke, National Institutes of Health, Department of Health and Human Services; and by the Sankofa Health Initiative, an intramural organization at University of Alabama at Birmingham.

\section{Author Information}

Corresponding Author: George Howard, DrPH, Professor, Department of Biostatistics, School of Public Health, University of Alabama at Birmingham, 1720 2nd Ave South, Birmingham, AL 35294-0022. Telephone: 205-934-4905. E-mail: ghoward@uab.edu.

Author Affiliations: Frederick Peace, Virginia J. Howard, School of Public Health, University of Alabama at Birmingham, Birmingham, Alabama.

\section{References}

1. US Burden of Disease Collaborators. The state of US health, 1990-2010: burden of diseases, injuries, and risk factors. JAMA 2013;310(6):591-608. CrossRef 原 PubMed

2. Lewis K, Burd-Sharps S. A century apart - new measures of well-being for U.S. racial and ethnic groups. Brooklyn (NY): American Human Development Project, Social Science Research Council; 2010. http://www.measureofamerica.org/wpcontent/uploads/2010/o4/A_Century_Apart.pdf. Accessed September 1, 2013.

3. Murray CJL, Kulkarni SC, Muchaud C, Tomijima N, Bulzacchelli MT, Iandiorio TJ, et al. Eight Americas: investigating mortality

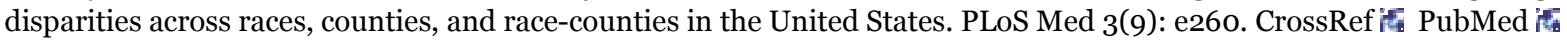

4. Compressed mortality file, 1999-2009. CDC WONDER online database, compiled from compressed mortality file 1999-2009, series 20, no. 20. Centers for Disease Control and Prevention, National Center for Health Statistics; 2012.

http://wonder.cdc.gov/. Accessed November 20, 2013.

5. Arias E. United States life tables, 2007. National vital statistics reports, vol. 59, no. 9. Hyattsville (MD): National Center for Health Statistics; 2011. p. 1-60. 
6. Wang H, Schumacher AE, Levitz CE, Mokdadd AH, Murray CJ. Left behind: widening disparities in males and females in US county life expectancy, 1985-2010. Popul Health Metr 2013;11(1):8.. CrossRef is PubMed it

7. Ezzati M, Friedman AB, Kulkarni SC, Murray CJ. The reversal of fortunes: trends in county mortality and cross-county mortality disparities in the United States. PloS Med 2008;5(4):e66. CrossRef

8. Arias E, Schauman WS, Eschbach K, Sorlie PD, Backlund E. The validity of race and Hispanic origin reporting on death certificates in the United States. Vital Health Stat 2 2008;(148):1-23. PubMed it

9. Halanych JH, Shuaib F, Parmar G, Tanikella R, Howard VJ, Roth DL, et al. Agreement on cause of death between proxies, death certificates, and clinician adjudicators in the Reasons for Geographic and Racial Differences in Stroke (REGARDS) study. Am J Epidemiol 2011;173(11):1319-26. CrossRef it PubMed if

10. Howard G. Ancel Keys Lecture: Adventures (and misadventures) in understanding (and reducing) disparities in stroke mortality. Stroke 2013;44(11):3254-9. CrossRef i PubMed it

11. Dwyer-Lindgren L, Mokdad AH, Srebotnjak T, Flaxman AD, Hansen GM, Murray CJL. Cigarette smoking in US counties: 1996 -2012. Popul Health Metr 2014;12(1):5. CrossRef it PubMed

\section{Tables}

Table 1. No. (\%) of People Who Died of Any of the 25 Leading Causes of Deatha, by Racial/Ethnic Group ${ }^{b}$, United States, 1999-2010

\begin{tabular}{|c|c|c|c|c|c|c|}
\hline \multirow[b]{2}{*}{ Category } & \multirow[b]{2}{*}{ Total } & \multicolumn{5}{|c|}{ Racial/Ethnic Group } \\
\hline & & $\begin{array}{l}\text { Non-Hispanic } \\
\text { White }\end{array}$ & $\begin{array}{l}\text { Non- } \\
\text { Hispanic } \\
\text { Black }\end{array}$ & $\begin{array}{l}\text { Hispanic } \\
\text { White }\end{array}$ & $\begin{array}{c}\text { Non-Hispanic } \\
\text { American Indian } \\
\text { or Alaska Native }\end{array}$ & $\begin{array}{l}\text { Non-Hispanic } \\
\text { Asian or Pacific } \\
\text { Islander }\end{array}$ \\
\hline Person-years at risk ${ }^{c}$ & $3,486,559,143$ & $2,384,810,893$ & $445,142,145$ & $463,832,712$ & $29,273,028$ & $163,500,365$ \\
\hline \multicolumn{7}{|l|}{ ICD-10 subchapter group } \\
\hline $\begin{array}{l}\text { C00-C97: Malignant } \\
\text { neoplasms }\end{array}$ & $\begin{array}{r}6,694,576 \\
(23)\end{array}$ & $5,484,107(23)$ & $751,193(22)$ & $298,644(20)$ & $27,579(18)$ & $133,053(27)$ \\
\hline $\begin{array}{l}\text { I20-I25: Ischemic heart } \\
\text { diseases }\end{array}$ & $\begin{array}{r}5,400,064 \\
(19)\end{array}$ & $4,503,062(19)$ & $548,407(16)$ & $241,062(16)$ & $20,851(13)$ & $86,682(17)$ \\
\hline $\begin{array}{l}\text { I30-I51: Other forms of } \\
\text { heart disease }\end{array}$ & $1,878,942(6)$ & $1,573,578(7)$ & $211,619(6)$ & $62,144(4)$ & $7,105(5)$ & $24,496(5)$ \\
\hline $\begin{array}{l}\text { I60-I69: Cerebrovascular } \\
\text { diseases }\end{array}$ & $1,772,800(6)$ & $1,434,266(6)$ & $211,205(6)$ & $78,900(5)$ & $6,538(4)$ & $41,891(8)$ \\
\hline $\begin{array}{l}\text { J40-J47: Chronic lower } \\
\text { respiratory diseases }\end{array}$ & $1,538,164(5)$ & $1,382,607(6)$ & $94,921(3)$ & $39,317(3)$ & $6,128(4)$ & $15,191(3)$ \\
\hline $\begin{array}{l}\text { E10-E14: Diabetes } \\
\text { mellitus }\end{array}$ & $853,442(3)$ & $607,583(3)$ & $147,577(4)$ & $71,592(5)$ & $8,808(6)$ & $17,882(4)$ \\
\hline $\begin{array}{l}\text { G30-G31: Other } \\
\text { degenerative diseases of } \\
\text { the nervous system }\end{array}$ & $826,704(3)$ & $740,689(3)$ & $49,980(1)$ & $26,741(2)$ & $1,829(1)$ & $7,465(2)$ \\
\hline $\begin{array}{l}\text { W00-X59: Other external } \\
\text { causes of accidental injury }\end{array}$ & $783,996(3)$ & $627,772(3)$ & $82,237(2)$ & $54,955(4)$ & $8,204(5)$ & $10,828(2)$ \\
\hline $\begin{array}{l}\text { F01-F09: Organic, } \\
\text { including symptomatic, } \\
\text { mental disorders }\end{array}$ & $759,587(3)$ & $667,749(3)$ & $58,872(2)$ & $22,367(2)$ & $1,833(1)$ & $8,766(2)$ \\
\hline $\begin{array}{l}\text { J09-J18: Influenza and } \\
\text { pneumonia }\end{array}$ & $711,031(2)$ & $591,688(3)$ & $66,133(2)$ & $34,193(2)$ & $3,777(2)$ & $15,240(3)$ \\
\hline $\begin{array}{l}\text { I10-I15: Hypertensive } \\
\text { diseases }\end{array}$ & $646,393(2)$ & $451,799(2)$ & $144,797(4)$ & $33,624(2)$ & $2,501(2)$ & $13,672(3)$ \\
\hline $\begin{array}{l}\text { V01-V99: Transport } \\
\text { accidents }\end{array}$ & $536,681(2)$ & $384,677(2)$ & $65,348(2)$ & $65,716(4)$ & $9,482(6)$ & $11,458(2)$ \\
\hline N17-N19: Renal failure & $493,520(2)$ & $365,965(2)$ & $90,113(3)$ & $26,050(2)$ & $2,909(2)$ & $8,483(2)$ \\
\hline K70-K76: Diseases of liver & $445,324(2)$ & $331,776(1)$ & $44,750(1)$ & $53,549(4)$ & $8,902(6)$ & $6,347(1)$ \\
\hline \multirow[t]{2}{*}{$\begin{array}{l}\text { A30-A49: Other bacterial } \\
\text { diseases }\end{array}$} & $424,411(1)$ & $319,234(1)$ & $75,627(2)$ & $20,828(1)$ & $2,609(2)$ & $6,113(1)$ \\
\hline & $408,985(1)$ & $348,736(1)$ & $38,745(1)$ & $14,061(1)$ & $1,439(1)$ & $6,004(1)$ \\
\hline
\end{tabular}




\begin{tabular}{|c|c|c|c|c|c|c|}
\hline \multirow[b]{2}{*}{ Category } & \multirow[b]{2}{*}{ Total } & \multicolumn{5}{|c|}{ Racial/Ethnic Group } \\
\hline & & $\begin{array}{l}\text { Non-Hispanic } \\
\text { White }\end{array}$ & $\begin{array}{l}\text { Non- } \\
\text { Hispanic } \\
\text { Black }\end{array}$ & $\begin{array}{l}\text { Hispanic } \\
\text { White }\end{array}$ & $\begin{array}{l}\text { Non-Hispanic } \\
\text { American Indian } \\
\text { or Alaska Native }\end{array}$ & $\begin{array}{l}\text { Non-Hispanic } \\
\text { Asian or Pacific } \\
\text { Islander }\end{array}$ \\
\hline \multicolumn{7}{|l|}{$\begin{array}{l}\text { I70-I78: Diseases of } \\
\text { arteries, arterioles, and } \\
\text { capillaries }\end{array}$} \\
\hline $\begin{array}{l}\text { X60-X84: Intentional self } \\
\text {-harm }\end{array}$ & $393,603(1)$ & $331,714(1)$ & $23,433(1)$ & $25,101(2)$ & $4,219(3)$ & $9,136(2)$ \\
\hline $\begin{array}{l}\text { K55-K63: Other diseases } \\
\text { of intestines }\end{array}$ & $251,124(1)$ & $211,341(1)$ & $24,955(1)$ & $10,538(1)$ & $1,321(1)$ & $2,969(1)$ \\
\hline $\begin{array}{l}\text { J60-J70: Lung diseases } \\
\text { due to external agents }\end{array}$ & $214,234(1)$ & $185,016(1)$ & $18,528(1)$ & $6,919(0)$ & $851(1)$ & $2,920(1)$ \\
\hline $\begin{array}{l}\text { G20-G25: Extrapyramidal } \\
\text { and movement disorders }\end{array}$ & $225,214(1)$ & $205,434(1)$ & $8,079(0)$ & $7,761(1)$ & $633(0)$ & $3,307(1)$ \\
\hline X85-Y09: Assault & $204,201(1)$ & $64,483(0)$ & $96,072(3)$ & $36,787(2)$ & $2,654(2)$ & $4,205(1)$ \\
\hline $\begin{array}{l}\text { J80-J84: Other respiratory } \\
\text { diseases principally } \\
\text { affecting the interstitium }\end{array}$ & $199,234(1)$ & $166,500(1)$ & $14,049(0)$ & $13,247(1)$ & $1,524(1)$ & $3,914(1)$ \\
\hline $\begin{array}{l}\text { E70-E88: Metabolic } \\
\text { disorders }\end{array}$ & $198,649(1)$ & $165,623(1)$ & $21,016(1)$ & $8,090(1)$ & $884(1)$ & $3,036(1)$ \\
\hline $\begin{array}{l}\text { R95-R99: Ill-defined and } \\
\text { unknown causes of } \\
\text { mortality }\end{array}$ & $197,958(1)$ & $143,082(1)$ & $34,611(1)$ & $15,639(1)$ & $1,923(1)$ & $2,703(1)$ \\
\hline $\begin{array}{l}\text { N30-N39: Other diseases } \\
\text { of urinary system }\end{array}$ & $165,358(1)$ & $137,866(1)$ & $18,141(1)$ & $6,491(0)$ & $677(0)$ & $2,183(0)$ \\
\hline All other causes & $\begin{array}{r}2,840,148 \\
(10)\end{array}$ & $2,091,320(9)$ & $481,042(14)$ & $199,533(14)$ & $19,722(13)$ & $48,531(10)$ \\
\hline
\end{tabular}

Abbreviations: ICD-10, International Classification of Diseases, 10th Revision.

a Source: Wide-Ranging Online Data for Epidemiologic Research (WONDER) system supported by the Centers for Disease Control and Prevention (4). Categories of causes of death established by the ICD-10.

b Because the number of deaths was too small to provide stable estimates, our racial/ethnic classification excluded a small number of Hispanic American Indians/Alaska Natives, Hispanic Asians/Pacific Islanders, and Hispanic blacks from the analyses (collectively 4,072,827 of $3,530,708,204[0.1 \%]$ of the total person-years at risk).

c Sum of the population in each of the 12 years of study.

Table 2. Age-Adjusted Mortality Rates for the 25 Leading Causes Of Deatha, by Racial/Ethnic Group ${ }^{b}$, United States, 1999-2010

\begin{tabular}{|c|c|c|c|c|c|}
\hline \multirow[b]{2}{*}{ ICD-10 Subchapter Groupc } & \multicolumn{5}{|c|}{ Age-Adjusted Mortality Rate } \\
\hline & $\begin{array}{c}\text { Non- } \\
\text { Hispanic } \\
\text { White }\end{array}$ & $\begin{array}{c}\text { Non- } \\
\text { Hispanic } \\
\text { Black }\end{array}$ & $\begin{array}{l}\text { Hispanic } \\
\text { White }\end{array}$ & $\begin{array}{l}\text { Non-Hispanic American } \\
\text { Indian or Alaska Native }\end{array}$ & $\begin{array}{l}\text { Non-Hispanic Asian } \\
\text { or Pacific Islander }\end{array}$ \\
\hline C00-C97: Malignant neoplasms & 188.51 & 229.39 & 131.72 & 150.97 & 113.41 \\
\hline I20-I25: Ischemic heart diseases & 151.27 & 179.46 & 127.12 & 127.30 & 86.67 \\
\hline $\begin{array}{l}\text { I30-I51: Other forms of heart } \\
\text { disease }\end{array}$ & 52.77 & 67.22 & 31.27 & 43.67 & 24.70 \\
\hline I60-I69: Cerebrovascular diseases & 47.96 & 69.28 & 40.28 & 42.61 & 41.54 \\
\hline $\begin{array}{l}\text { J40-J47: Chronic lower respiratory } \\
\text { diseases }\end{array}$ & 46.89 & 30.70 & 21.32 & 38.37 & 15.87 \\
\hline E10-E14: Diabetes mellitus & 20.78 & 46.38 & 34.19 & 49.19 & 16.95 \\
\hline $\begin{array}{l}\text { G30-G31: Other degenerative } \\
\text { diseases of the nervous system }\end{array}$ & 24.30 & 18.93 & 16.80 & 15.00 & 8.79 \\
\hline $\begin{array}{l}\text { W00-X59: Other external causes of } \\
\text { accidental injury }\end{array}$ & 23.66 & 21.35 & 16.25 & 33.81 & 9.02 \\
\hline $\begin{array}{l}\text { F01-F09: Organic, including } \\
\text { symptomatic, mental disorders }\end{array}$ & 21.77 & 22.27 & 14.26 & 15.41 & 10.55 \\
\hline
\end{tabular}




\begin{tabular}{|c|c|c|c|c|c|}
\hline \multirow[b]{2}{*}{ ICD-10 Subchapter Groupc } & \multicolumn{5}{|c|}{ Age-Adjusted Mortality Rate } \\
\hline & $\begin{array}{l}\text { Non- } \\
\text { Hispanic } \\
\text { White }\end{array}$ & $\begin{array}{c}\text { Non- } \\
\text { Hispanic } \\
\text { Black }\end{array}$ & $\begin{array}{l}\text { Hispanic } \\
\text { White }\end{array}$ & $\begin{array}{l}\text { Non-Hispanic American } \\
\text { Indian or Alaska Native }\end{array}$ & $\begin{array}{l}\text { Non-Hispanic Asian } \\
\text { or Pacific Islander }\end{array}$ \\
\hline J09-J18: Influenza and pneumonia & 19.75 & 22.06 & 18.13 & 24.53 & 16.59 \\
\hline I10-I15: Hypertensive diseases & 15.15 & 45.27 & 16.76 & 14.92 & 13.95 \\
\hline V01-V99: Transport accidents & 15.74 & 15.10 & 14.81 & 32.99 & 7.46 \\
\hline N17-N19: Renal failure & 12.32 & 28.99 & 12.84 & 17.28 & 8.40 \\
\hline K70-K76: Diseases of liver & 11.81 & 11.73 & 19.45 & 36.09 & 4.96 \\
\hline A30-A49: Other bacterial diseases & 10.90 & 24.03 & 9.58 & 14.30 & 5.79 \\
\hline $\begin{array}{l}\text { I70-I78: Diseases of arteries, } \\
\text { arterioles and capillaries }\end{array}$ & 11.71 & 12.88 & 7.36 & 9.36 & 5.98 \\
\hline X60-X84: Intentional self-harm & 13.22 & 5.39 & 6.06 & 14.15 & 5.68 \\
\hline $\begin{array}{l}\text { K55-K63: Other diseases of } \\
\text { intestines }\end{array}$ & 7.12 & 8.16 & 5.37 & 8.19 & 3.00 \\
\hline $\begin{array}{l}\text { G20-G25: Extrapyramidal and } \\
\text { movement disorders }\end{array}$ & 6.89 & 2.93 & 4.56 & 4.77 & 3.61 \\
\hline $\begin{array}{l}\text { J60-J70: Lung diseases due to } \\
\text { external agents }\end{array}$ & 6.16 & 6.45 & 3.90 & 5.89 & 3.29 \\
\hline X85-Y09: Assault & 2.73 & 20.63 & 7.22 & 8.87 & 2.47 \\
\hline $\begin{array}{l}\text { R95-R99: Ill-defined and unknown } \\
\text { causes of mortality }\end{array}$ & 5.55 & 8.35 & 3.87 & 7.20 & 1.92 \\
\hline $\begin{array}{l}\text { J80-J84: Other respiratory diseases } \\
\text { principally affecting the interstitium }\end{array}$ & 5.68 & 4.21 & 6.46 & 9.25 & 3.77 \\
\hline E70-E88: Metabolic disorders & 5.70 & 6.79 & 3.66 & 5.04 & 2.90 \\
\hline $\begin{array}{l}\text { N30-N39: Other diseases of urinary } \\
\text { system }\end{array}$ & 4.57 & 6.48 & 3.70 & 4.79 & 2.39 \\
\hline
\end{tabular}

Abbreviations: ICD-10, International Classification of Diseases, 10th Revision.

a Source: Wide-Ranging Online Data for Epidemiologic Research (WONDER) system supported by the Centers for Disease Control and Prevention (4). Categories of causes of death established by the ICD-10.

b Because the number of deaths was too small to provide stable estimates, our racial/ethnic classification excluded a small number of Hispanic American Indians/Alaska Natives, Hispanic Asians/Pacific Islanders, and Hispanic blacks from the analyses (collectively 4,072,827 of $3,530,708,204[0.1 \%]$ of the total person-years at risk).

c Ranked in decreasing order by death rate for the non-Hispanic white population.

\section{Appendix. Supplemental Tables and Figures}

Supplemental Table 1. Data for Figure on Age-Adjusted Mortality Ratio (AAMR) and Difference in Years of Life Lost (dYLL), by Racial/Ethnic Groupa for the 25 Leading Causes of Death as Classified by the ICD-10, United States, 1999-2010

\begin{tabular}{|l|r|r|r|r|r|r|r|r|}
\hline & \multicolumn{2}{|c|}{$\begin{array}{c}\text { Non-Hispanic } \\
\text { Blacka }\end{array}$} & \multicolumn{2}{c|}{ Hispanic White } & \multicolumn{2}{c|}{$\begin{array}{c}\text { Non-Hispanic American } \\
\text { Indian or Alaskan Native }\end{array}$} & $\begin{array}{c}\text { Non-Hispanic Asian or } \\
\text { Pacific Islander }\end{array}$ \\
\cline { 2 - 9 } ICD-10 Subchapter Group & AAMR & \multicolumn{1}{|c|}{ dYLL } & AAMR & \multicolumn{1}{c|}{ dYLL } & \multicolumn{1}{c|}{ AAMR } & \multicolumn{1}{c|}{ dYLL } & AAMR & dYLL \\
\hline C00-C97: Malignant neoplasms & 1.22 & $3,781,343$ & 0.70 & $-3,724,049$ & 0.80 & $-158,197$ & 0.60 & $-1,979,722$ \\
\hline $\begin{array}{l}\text { I20-I25: Ischemic heart } \\
\text { diseases }\end{array}$ & 1.19 & $2,725,283$ & 0.84 & $-1,728,080$ & 0.84 & $-11,696$ & 0.57 & $-1,368,421$ \\
\hline $\begin{array}{l}\text { I30-I51: Other forms of heart } \\
\text { disease }\end{array}$ & 1.27 & $2,052,395$ & 0.59 & $-814,436$ & 0.83 & 14,032 & 0.47 & $-500,768$ \\
\hline $\begin{array}{l}\text { I60-I69: Cerebrovascular } \\
\text { diseases }\end{array}$ & 1.44 & $2,000,212$ & 0.84 & $-83,787$ & 0.89 & 12,653 & 0.87 & $-30,913$ \\
\hline $\begin{array}{l}\text { J40-J47: Chronic lower } \\
\text { respiratory diseases }\end{array}$ & 0.65 & $-379,109$ & 0.45 & $-1,091,025$ & 0.82 & $-14,047$ & 0.34 & $-624,294$ \\
\hline E10-E14: Diabetes mellitus & 2.23 & $1,804,677$ & 1.65 & 352,592 & 2.37 & 117,812 & 0.82 & $-178,102$ \\
\hline $\begin{array}{l}\text { G30-G31: Other degenerative } \\
\text { diseases of the nervous system }\end{array}$ & 0.78 & $-147,356$ & 0.69 & $-172,533$ & 0.62 & $-11,371$ & 0.36 & $-154,368$ \\
& & & & &
\end{tabular}


Preventing Chronic Disease | The Contributions of Selected Diseases to Disparities in ... Page 12 of 18

\begin{tabular}{|c|c|c|c|c|c|c|c|c|}
\hline \multirow[b]{2}{*}{ ICD-10 Subchapter Group } & \multicolumn{2}{|c|}{$\begin{array}{l}\text { Non-Hispanic } \\
\text { Blacka }^{\mathbf{a}}\end{array}$} & \multicolumn{2}{|c|}{ Hispanic White } & \multicolumn{2}{|c|}{$\begin{array}{l}\text { Non-Hispanic American } \\
\text { Indian or Alaskan Native }\end{array}$} & \multicolumn{2}{|c|}{$\begin{array}{l}\text { Non-Hispanic Asian or } \\
\text { Pacific Islander }\end{array}$} \\
\hline & AAMR & dYLL & AAMR & dYLL & AAMR & dYLL & AAMR & dYLL \\
\hline $\begin{array}{l}\text { W00-X59: Other external } \\
\text { causes of accidental injury }\end{array}$ & 0.90 & $-84,254$ & 0.69 & $-1,389,452$ & 1.43 & 128,626 & 0.38 & $-917,067$ \\
\hline $\begin{array}{l}\text { F01-F09: Organic, including } \\
\text { symptomatic, mental disorders }\end{array}$ & 1.02 & 56,571 & 0.66 & $-146,607$ & 0.71 & $-7,328$ & 0.48 & $-107,692$ \\
\hline $\begin{array}{l}\text { J09-J18: Influenza and } \\
\text { pneumonia }\end{array}$ & 1.12 & 415,726 & 0.92 & $-78,038$ & 1.24 & 33,886 & 0.84 & $-94,824$ \\
\hline I10-I15: Hypertensive diseases & 2.99 & $2,349,699$ & 1.11 & 25,013 & 0.98 & 9,194 & 0.92 & $-72,527$ \\
\hline V01-V99: Transport accidents & 0.96 & $-190,089$ & 0.94 & $-548,674$ & 2.10 & 248,013 & 0.47 & $-724,126$ \\
\hline N17-N19: Renal failure & 2.35 & $1,228,893$ & 1.04 & 47,097 & 1.40 & 28,364 & 0.68 & $-73,046$ \\
\hline K70-K76: Diseases of liver & 0.99 & 90,599 & 1.65 & 421,214 & 3.06 & 218,017 & 0.42 & $-330,094$ \\
\hline $\begin{array}{l}\text { A30-A49: Other bacterial } \\
\text { diseases }\end{array}$ & 2.20 & 977,585 & 0.88 & $-82,001$ & 1.31 & 27,764 & 0.53 & $-122,342$ \\
\hline $\begin{array}{l}\text { I70-I78: Diseases of arteries, } \\
\text { arterioles and capillaries }\end{array}$ & 1.10 & 182,329 & 0.63 & $-160,671$ & 0.80 & $-3,370$ & 0.51 & $-94,127$ \\
\hline X60-X84: Intentional self-harm & 0.41 & $-1,242,755$ & 0.46 & $-1,494,701$ & 1.07 & 58,100 & 0.43 & $-543,803$ \\
\hline $\begin{array}{l}\text { K55-K63: Other diseases of } \\
\text { intestines }\end{array}$ & 1.15 & 169,834 & 0.75 & $-72,454$ & 1.15 & 8,210 & 0.42 & $-75,055$ \\
\hline $\begin{array}{l}\text { G20-G25: Extrapyramidal and } \\
\text { movement disorders }\end{array}$ & 0.43 & $-123,259$ & 0.66 & $-64,464$ & 0.69 & $-2,955$ & 0.52 & $-40,962$ \\
\hline $\begin{array}{l}\text { J60-J70: Lung diseases due to } \\
\text { external agents }\end{array}$ & 1.05 & 51,176 & 0.63 & $-82,442$ & 0.96 & 1,532 & 0.53 & $-52,448$ \\
\hline X85-Y09: Assault & 7.56 & $4,506,949$ & 2.64 & $1,249,884$ & 3.25 & 97,797 & 0.90 & $-25,887$ \\
\hline $\begin{array}{l}\text { R95-R99: Ill-defined and } \\
\text { unknown causes of mortality }\end{array}$ & 1.50 & 787,630 & 0.70 & $-405,927$ & 1.30 & 40,471 & 0.35 & $-214,763$ \\
\hline $\begin{array}{l}\text { J80-J84: Other respiratory } \\
\text { diseases principally affecting } \\
\text { the interstitium }\end{array}$ & 0.74 & $-43,617$ & 1.14 & 9,302 & 1.63 & 13,704 & 0.66 & $-47,064$ \\
\hline E70-E88: Metabolic disorders & 1.19 & 44,249 & 0.64 & $-180,021$ & 0.88 & -814 & 0.51 & $-81,486$ \\
\hline $\begin{array}{l}\text { N30-N39: Other diseases of } \\
\text { urinary system }\end{array}$ & 1.42 & 96,243 & 0.81 & $-24,589$ & 1.05 & 2,703 & 0.52 & $-29,071$ \\
\hline
\end{tabular}

Abbreviations: ICD-10, International Classification of Diseases, 10th Revision.

a Because the number of deaths was too small to provide stable estimates, our racial/ethnic classification excluded a small number of Hispanic American Indians/Alaska Natives, Hispanic Asians/Pacific Islanders, and Hispanic blacks from the analyses (collectively 4,072,827 of $3,530,708,204[0.1 \%]$ of the total person-years at risk).

b Each group was compared with non-Hispanic whites. 
Preventing Chronic Disease $\mid$ The Contributions of Selected Diseases to Disparities in ... Page 13 of 18

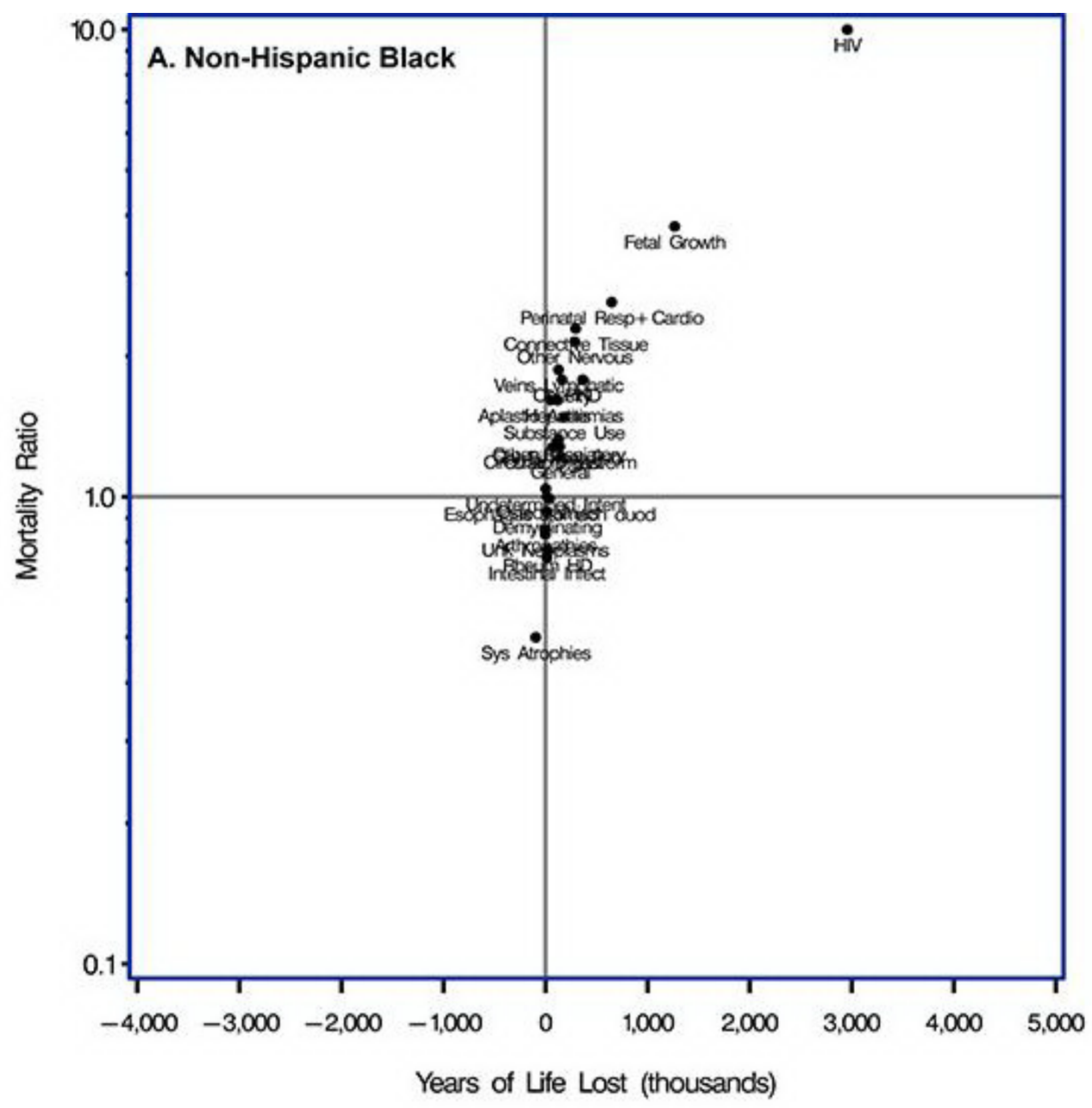

Detum

Years of Life Lost (thousands) 
Preventing Chronic Disease $\mid$ The Contributions of Selected Diseases to Disparities in ... Page 14 of 18

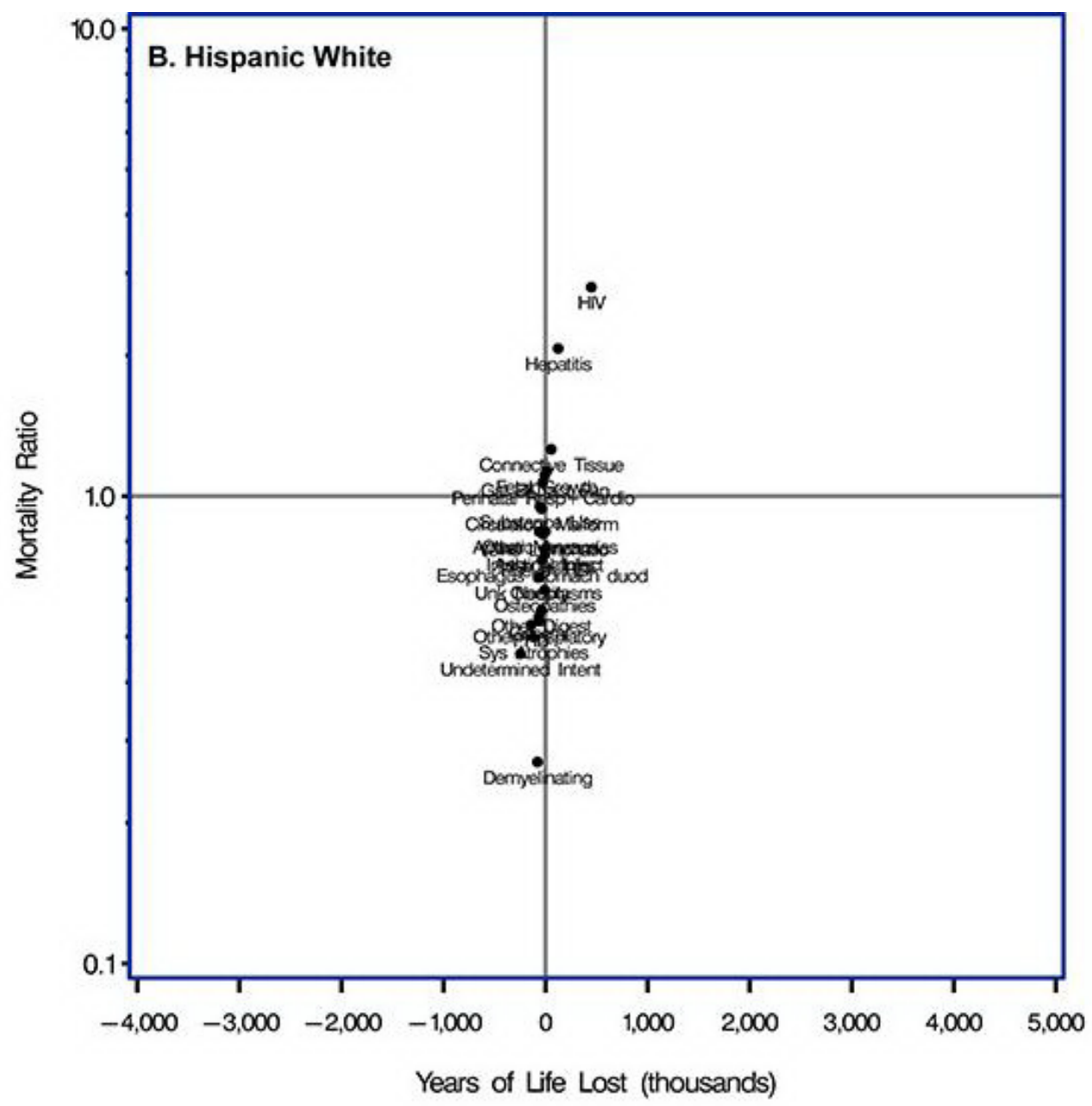


Preventing Chronic Disease $\mid$ The Contributions of Selected Diseases to Disparities in ... Page 15 of 18

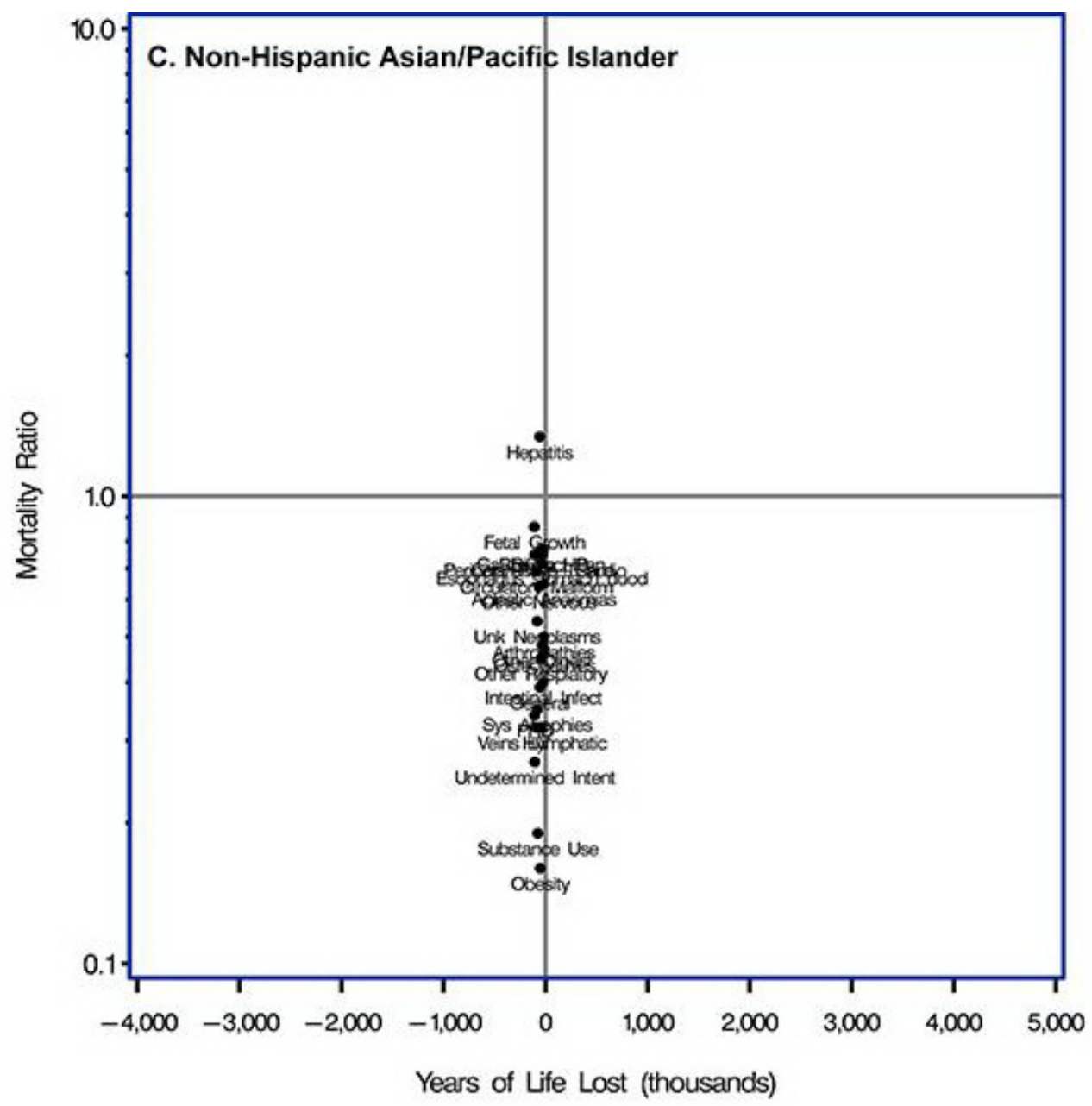




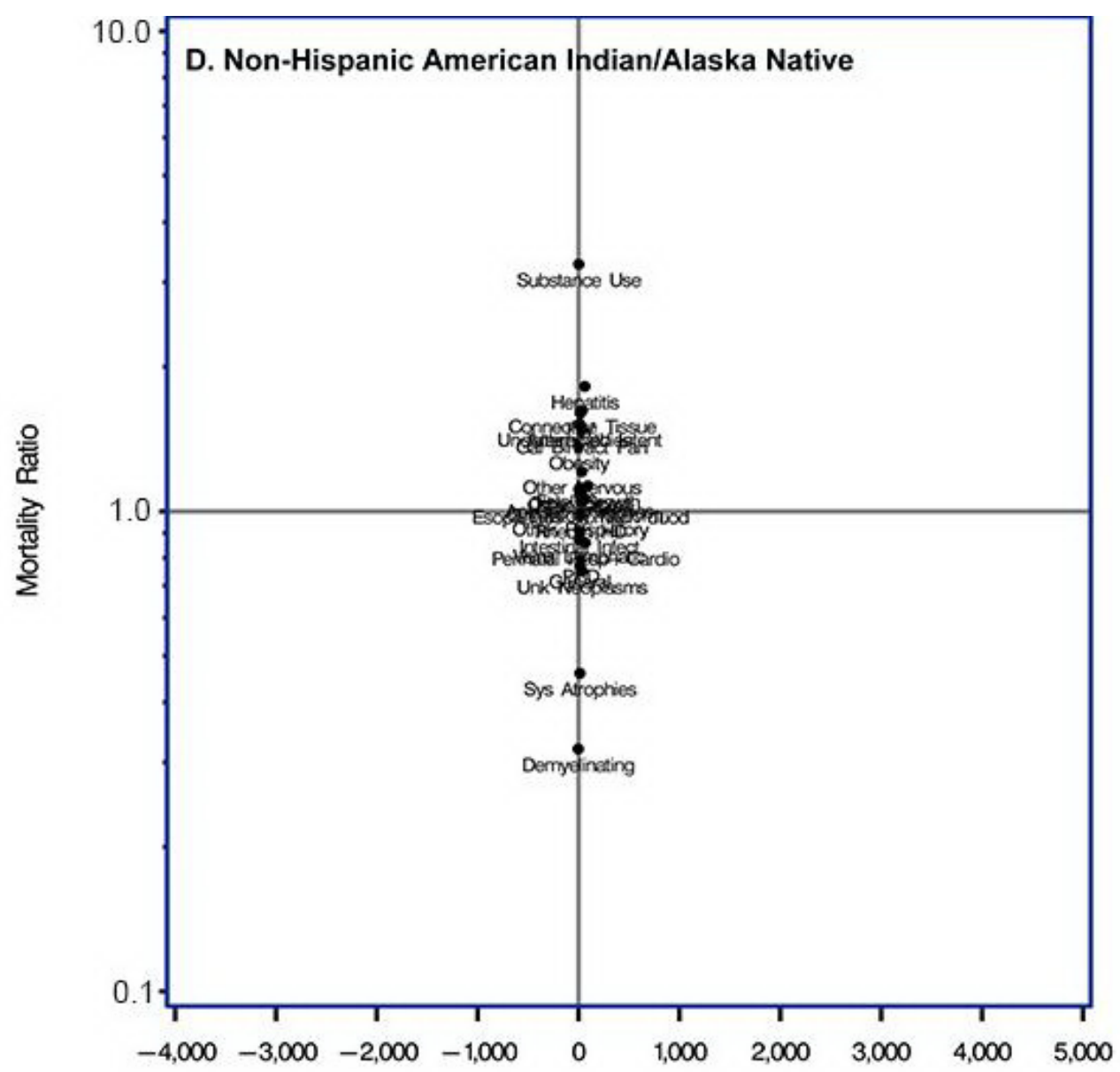

Years of Life Lost (thousands)

Supplemental Figure. Scatterplots of relative disparities (age-adjusted mortality ratio) and absolute disparities (years of life lost) for each of 4 racial/ethnic minority groups compared with the non-Hispanic white population for the 26th- to $50^{\text {th }}$-ranked leading causes of death in the United States, 1999-2010. Causes of death were categorized according to the International Classification of Diseases, $10^{\text {th }}$ Revision. Scatterplot A is for non-Hispanic blacks; B is for Hispanic whites; $\mathrm{C}$ is for non-Hispanic Asians/Pacific Islanders; and D is for non-Hispanic American Indians/Alaska Natives. Abbreviations for categories of causes of death were used to provide clearer plots. Abbreviations: PHD, pulmonary heart disease and diseases of pulmonary circulation; General, general symptoms and signs; Unk Neoplasms, neoplasms of uncertain or unknown behavior; HIV, human immunodeficiency virus disease; Substance Use, mental or behavioral disorders due to psychoactive substance use; Gal BilTract Pan, disorders of gallbladder, biliary tract, or pancreas; Other Digest, other diseases of the digestive system; Other Respiratory, other diseases of the respiratory system; Other Nervous, other disorders of the nervous system; Sys Atrophies, systemic atrophies primarily affecting the central nervous system; Esophagus stomach duod, diseases of esophagus, stomach, or duodenum; Hepatitis, viral hepatitis; Intestinal Infect, intestinal infectious diseases; Undetermined Intent, event of undetermined intent; Fetal Growth, disorders related to length of gestation or fetal growth; Connective Tissue, systemic connective tissue disorders; Obesity, obesity or other hyperalimentation; Arthropathies, arthropathies; Veins Lymphatic, diseases of veins, lymphatic vessels, or lymph nodes, not elsewhere classified; Circulatory Malform, congenital malformations of the circulatory system.

Supplemental Table 2. Data for Supplemental Figure on Age-Adjusted Mortality Ratio (AAMR) and Difference in Years of Life Lost (dYLL), Plus Age-Adjusted Mortality Rates, by Racial/Ethnic Groupa, for the 26th- to 5oth-Ranked Causes of Death as Classified by the ICD-10, United States, 1999-2010b

\begin{tabular}{|c|c|c|c|c|c|c|c|c|c|c|c|c|c|}
\hline \multirow{2}{*}{$\begin{array}{l}\text { ICD-10 } \\
\text { Subchapter } \\
\text { Group }\end{array}$} & \multirow{2}{*}{$\begin{array}{c}\begin{array}{c}\text { Non- } \\
\text { Hispanic } \\
\text { White }\end{array} \\
\text { Rate }\end{array}$} & \multicolumn{3}{|c|}{ Non-Hispanic Black } & \multicolumn{3}{|c|}{ Hispanic White } & \multicolumn{3}{|c|}{$\begin{array}{c}\text { Non-Hispanic } \\
\text { American Indian or } \\
\text { Alaskan Native }\end{array}$} & \multicolumn{3}{|c|}{$\begin{array}{l}\text { Non-Hispanic Asian or } \\
\text { Pacific Islander }\end{array}$} \\
\hline & & AAMR & Rate & dYLL & AAMR & Rate & dYLL & AAMR & Rate & dYLL & AAMR & Rate & dYLL \\
\hline $\begin{array}{l}\text { A00-A09: } \\
\text { Intestinal } \\
\text { infectious } \\
\text { diseases }\end{array}$ & 1.81 & 1.34 & 0.74 & 14,275 & 1.40 & 0.77 & $-1,722$ & 1.64 & 0.91 & 1,569 & 0.72 & 0.40 & $-15,603$ \\
\hline
\end{tabular}




\begin{tabular}{|c|c|c|c|c|c|c|c|c|c|c|c|c|c|}
\hline \multirow{2}{*}{$\begin{array}{l}\text { ICD-10 } \\
\text { Subchapter } \\
\text { Group }\end{array}$} & \multirow{2}{*}{$\begin{array}{c}\begin{array}{c}\text { Non- } \\
\text { Hispanic } \\
\text { White }\end{array} \\
\text { Rate } \\
\end{array}$} & \multicolumn{3}{|c|}{ Non-Hispanic Black } & \multicolumn{3}{|c|}{ Hispanic White } & \multicolumn{3}{|c|}{$\begin{array}{c}\text { Non-Hispanic } \\
\text { American Indian or } \\
\text { Alaskan Native }\end{array}$} & \multicolumn{3}{|c|}{$\begin{array}{l}\text { Non-Hispanic Asian or } \\
\text { Pacific Islander }\end{array}$} \\
\hline & & AAMR & Rate & dYLL & AAMR & Rate & dYLL & AAMR & Rate & dYLL & AAMR & Rate & dYLL \\
\hline $\begin{array}{l}\text { B15-B19: Viral } \\
\text { hepatitis }\end{array}$ & 1.77 & 2.85 & 1.61 & 118,894 & 3.65 & 2.07 & 139,425 & 3.21 & 1.82 & 13,044 & 2.37 & 1.34 & $-7,360$ \\
\hline $\begin{array}{l}\text { B20-B24: Human } \\
\text { immunodeficiency } \\
\text { virus [HIV] } \\
\text { disease }\end{array}$ & 1.80 & 19.43 & 10.81 & $2,957,106$ & 5.04 & 2.80 & 475,611 & 2.88 & 1.60 & 12,361 & 0.57 & 0.32 & $-86,854$ \\
\hline $\begin{array}{l}\text { D37-D48: } \\
\text { Neoplasms of } \\
\text { uncertain or } \\
\text { unknown behavior }\end{array}$ & 4.36 & 3.61 & 0.83 & $-2,217$ & 2.92 & 0.67 & $-54,049$ & 3.29 & 0.75 & $-3,251$ & 2.37 & 0.54 & $-43,205$ \\
\hline $\begin{array}{l}\text { D60-D64: Aplastic } \\
\text { and other } \\
\text { anemias }\end{array}$ & 1.12 & 1.81 & 1.61 & 51,909 & 0.94 & 0.84 & 1,019 & 1.21 & 1.08 & 1,030 & 0.73 & 0.65 & $-4,250$ \\
\hline $\begin{array}{l}\text { E65-E68: Obesity } \\
\text { and other } \\
\text { hyperalimentation }\end{array}$ & 1.36 & 2.43 & 1.78 & 162,285 & 0.91 & 0.67 & $-44,564$ & 1.85 & 1.36 & 5,779 & 0.22 & 0.16 & $-55,233$ \\
\hline $\begin{array}{l}\text { F10-F19: Mental } \\
\text { and behavioral } \\
\text { disorders due to } \\
\text { psychoactive } \\
\text { substance use }\end{array}$ & 3.03 & 4.49 & 1.48 & 182,083 & 2.87 & 0.95 & $-18,684$ & 9.88 & 3.27 & 66,826 & 0.57 & 0.19 & $-140,138$ \\
\hline $\begin{array}{l}\text { G10-G12: } \\
\text { Systemic } \\
\text { atrophies } \\
\text { primarily affecting } \\
\text { the central } \\
\text { nervous system }\end{array}$ & 2.61 & 1.30 & 0.50 & $-95,134$ & 1.30 & 0.50 & $-101,981$ & 1.20 & 0.46 & $-8,240$ & 0.92 & 0.35 & $-59,034$ \\
\hline $\begin{array}{l}\text { G35-G37: } \\
\text { Demyelinating } \\
\text { diseases of the } \\
\text { central nervous } \\
\text { system }\end{array}$ & 1.26 & 1.16 & 0.93 & 17,085 & 0.34 & 0.27 & $-69,460$ & 0.40 & 0.32 & $-5,135$ & 0.12 & 0.09 & $-45,209$ \\
\hline $\begin{array}{l}\text { G90-G98: Other } \\
\text { disorders of the } \\
\text { nervous system }\end{array}$ & 2.42 & 5.19 & 2.15 & 285,330 & 2.04 & 0.84 & $-42,216$ & 2.93 & 1.21 & 4,760 & 1.54 & 0.64 & $-39,268$ \\
\hline $\begin{array}{l}\text { I05-I09: Chronic } \\
\text { rheumatic heart } \\
\text { diseases }\end{array}$ & 1.14 & 0.88 & 0.77 & 17,729 & 0.86 & 0.75 & $-2,497$ & 1.12 & 0.98 & 1,644 & 0.88 & 0.77 & -160 \\
\hline $\begin{array}{l}\text { I26-I28: } \\
\text { Pulmonary heart } \\
\text { disease and } \\
\text { diseases of } \\
\text { pulmonary } \\
\text { circulation }\end{array}$ & 4.32 & 7.68 & 1.78 & 364,562 & 2.30 & 0.53 & $-117,555$ & 3.39 & 0.78 & -617 & 1.46 & 0.34 & $-82,762$ \\
\hline $\begin{array}{l}\text { I80-I89: Diseases } \\
\text { of veins, } \\
\text { lymphatic vessels } \\
\text { and lymph nodes, } \\
\text { not elsewhere } \\
\text { classified }\end{array}$ & 1.22 & 2.28 & 1.87 & 127,804 & 1.02 & 0.83 & $-18,277$ & 1.06 & 0.87 & -104 & 0.39 & 0.32 & $-27,836$ \\
\hline $\begin{array}{l}\text { J96-J98: Other } \\
\text { diseases of the } \\
\text { respiratory } \\
\text { system }\end{array}$ & 2.67 & 3.56 & 1.33 & 128,686 & 1.44 & 0.54 & $-47,483$ & 2.64 & 0.99 & 1,280 & 1.20 & 0.45 & $-32,465$ \\
\hline $\begin{array}{l}\text { K20-K31: } \\
\text { Diseases of } \\
\text { esophagus, } \\
\text { stomach and } \\
\text { duodenum }\end{array}$ & 2.25 & 2.23 & 0.99 & 39,723 & 1.63 & 0.73 & $-26,776$ & 2.36 & 1.05 & 1,944 & 1.62 & 0.72 & $-20,335$ \\
\hline $\begin{array}{l}\text { K80-K86: } \\
\text { Disorders of }\end{array}$ & 2.59 & 3.38 & 1.31 & 111,881 & 2.86 & 1.11 & 4,194 & 3.80 & 1.47 & 6,930 & 1.99 & 0.77 & $-25,654$ \\
\hline
\end{tabular}




\begin{tabular}{|c|c|c|c|c|c|c|c|c|c|c|c|c|c|}
\hline \multirow{2}{*}{$\begin{array}{l}\text { ICD-10 } \\
\text { Subchapter } \\
\text { Group }\end{array}$} & \multirow{2}{*}{$\begin{array}{c}\begin{array}{c}\text { Non- } \\
\text { Hispanic } \\
\text { White }\end{array} \\
\text { Rate }\end{array}$} & \multicolumn{3}{|c|}{ Non-Hispanic Black } & \multicolumn{3}{|c|}{ Hispanic White } & \multicolumn{3}{|c|}{$\begin{array}{c}\text { Non-Hispanic } \\
\text { American Indian or } \\
\text { Alaskan Native }\end{array}$} & \multicolumn{3}{|c|}{$\begin{array}{c}\text { Non-Hispanic Asian or } \\
\text { Pacific Islander }\end{array}$} \\
\hline & & AAMR & Rate & dYLL & AAMR & Rate & dYLL & AAMR & Rate & dYLL & AAMR & Rate & dYLL \\
\hline \multicolumn{14}{|l|}{$\begin{array}{l}\text { gallbladder, biliary } \\
\text { tract and } \\
\text { pancreas }\end{array}$} \\
\hline $\begin{array}{l}\text { K90-K92: Other } \\
\text { diseases of the } \\
\text { digestive system }\end{array}$ & 2.67 & 3.42 & 1.28 & 74,729 & 1.51 & 0.57 & $-34,489$ & 3.00 & 1.12 & 3,574 & 1.29 & 0.48 & $-26,618$ \\
\hline $\begin{array}{l}\text { M00-M25: } \\
\text { Arthropathies }\end{array}$ & 1.44 & 1.22 & 0.85 & 1,440 & 1.11 & 0.77 & $-5,434$ & 2.19 & 1.52 & 3,802 & 0.71 & 0.50 & $-12,552$ \\
\hline $\begin{array}{l}\text { M30-M35: } \\
\text { Systemic } \\
\text { connective tissue } \\
\text { disorders }\end{array}$ & 1.21 & 2.78 & 2.29 & 295,692 & 1.52 & 1.26 & 63,508 & 1.96 & 1.62 & 7,132 & 0.91 & 0.75 & 1,982 \\
\hline $\begin{array}{l}\text { M80-M94: } \\
\text { Osteopathies and } \\
\text { chondropathies }\end{array}$ & 1.07 & 1.07 & 1.00 & 15,003 & 0.67 & 0.63 & $-6,579$ & 1.19 & 1.11 & 994 & 0.51 & 0.47 & $-8,388$ \\
\hline $\begin{array}{l}\text { P05-P08: } \\
\text { Disorders related } \\
\text { to length of } \\
\text { gestation and } \\
\text { fetal growth }\end{array}$ & 1.12 & 4.24 & 3.79 & $1,265,783$ & 1.26 & 1.13 & 82,276 & 1.26 & 1.13 & 3,970 & 0.96 & 0.86 & $-20,805$ \\
\hline $\begin{array}{l}\text { P20-P29: } \\
\text { Respiratory and } \\
\text { cardiovascular } \\
\text { disorders specific } \\
\text { to the perinatal } \\
\text { period }\end{array}$ & 0.99 & 2.59 & 2.61 & 648,133 & 1.06 & 1.07 & 37,762 & 0.85 & 0.86 & $-3,830$ & 0.74 & 0.75 & $-32,546$ \\
\hline $\begin{array}{l}\text { Q20-Q28: } \\
\text { Congenital } \\
\text { malformations of } \\
\text { the circulatory } \\
\text { system }\end{array}$ & 1.27 & 1.63 & 1.28 & 138,912 & 1.20 & 0.94 & 10,650 & 1.34 & 1.06 & 4,250 & 0.88 & 0.69 & $-32,939$ \\
\hline $\begin{array}{l}\text { R50-R68: General } \\
\text { symptoms and } \\
\text { signs }\end{array}$ & 4.31 & 5.26 & 1.22 & 147,760 & 2.35 & 0.55 & $-53,582$ & 3.31 & 0.77 & 1,717 & 1.68 & 0.39 & $-44,484$ \\
\hline $\begin{array}{l}\text { Y10-Y34: Event of } \\
\text { undetermined } \\
\text { intent }\end{array}$ & 1.78 & 1.86 & 1.04 & 2,761 & 0.82 & 0.46 & $-209,729$ & 2.72 & 1.52 & 12,466 & 0.49 & 0.27 & $-107,190$ \\
\hline
\end{tabular}

Abbreviations: ICD-10, International Classification of Diseases, 10th Revision.

a Because the number of deaths was too small to provide stable estimates, our racial/ethnic classification excluded a small number of Hispanic American Indians/Alaska Natives, Hispanic Asians/Pacific Islanders, and Hispanic blacks from the analyses (collectively 4,072,827 of $3,530,708,204[0.1 \%]$ of the total person-years at risk).

b Each group was compared with non-Hispanic whites.

The opinions expressed by authors contributing to this journal do not necessarily reflect the opinions of the U.S. Department of Health and Human Services, the Public Health Service, the Centers for Disease Control and Prevention, or the authors' affiliated institutions.

For Questions About This Article Contact pcdeditor@cdc.gov

Page last reviewed: July 31, 2014

Page last updated: July 31, 2014

Content source: National Center for Chronic Disease Prevention and Health Promotion

Centers for Disease Control and Prevention 1600 Clifton Rd. Atlanta, GA 30333, USA 80o-CDC-INFO (800-232-4636) TTY: (888) 232-6348 - Contact CDC-INFO 